報
ORIGINAL PAPER
NO.
15

\title{
コークス炬耐火物の侵蝕に関する研究
}

\author{
青武旅・尾山竹涴 \\ (大阪大学産業科学研究所)
}

\section{Studies on Corrosion of Refractories in a Coke Oven}

\author{
By Takeo AO and Takeji OYAMA
}

(The Institute of Scientific and Industrial Research, Osaka Univ.)

\begin{abstract}
Changes of refractories, both silica and grog brick, after a long period of service in a by-product coke oven were studied. Sample bricks were taken from different parts of the oven. As they showed layered structure, chemical analysis, microscopic examination, estimation of mineral composition, determination of density, porosity and of water absorption were made on each layer. The results are summarized as under.
\end{abstract}

(1) Silica brick from the centre of coking chamber wall: In the first (hotest) layer, all of quartz has been converted into tridymite of lath-shape habit, whereas cristobalite content increases gradually towards the coke side (lower temperature layers). The impurities, such as iron oxide and lime, seem to have migrated from both of coke and flue side towards the mid-layer, where they reach maximum amount.

(2) Silica brick from oven door (jamb brick): Chief mineral composition is very much like to that of the brick from the wall, except that the impurities are concentrated on the flue side. Those impurities have come from flue side, whereas hitherto only those from coal ash were noticed.

(3) Grog bricks from the roof and sole of the coking chamber: The impurities are concentrated on those surfaces which are facing to coking chamber. There are many large cracks on the surface.

(4) Sulphur and carbon contents are slight in silica bricks. Sulphur seems to occur in forming ultramarine.

$$
\text { まえがき }
$$

本研究に用いたコークス炉はいわゆる日鉄複式コ一 クス炸 (14 トン，75 門) で，炤和 15 年から同 21 椞に至る約 6 年間にわたり使用されたものである. 燃 唯としては精製しない高炉力゙ス，都市ガスが主として 用いられ，石炭は北支開瀾炭，満洲炭が，後期飞は北 游道炭，九州炭も用いられ常に洗炭されていたとのこ とである。乾溜時間は 18～22 時間で炉内温度は㤘化 室で $1100^{\circ} \mathrm{C}$ を標準として操策され，乙たがって燃焼 室は $1200 \sim 1300^{\circ} \mathrm{C}$, 炻口では中央部より約 $80^{\circ} \mathrm{C}$ 低

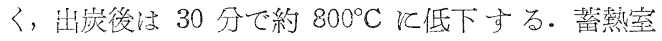
は熱变動が多いが上部で約 $1000^{\circ} \mathrm{C}$, 下部で約 $400^{\circ} \mathrm{C}$, 煙突下部附近で $250^{\circ} \mathrm{C}$ 程度と考学られるが，いずれ も正確な測定徝はない。使用酎火煝瓦は炭化室壁と堛 禁室の大部分は珪石煉瓦, 岸化室天井と炉敷はシャモ ッ卜揀瓦，蓄熱室下部は䗵石煉瓦が使用されていた。 このようなコークス炉の使用中打いて, 煉瓦がぞの ようね変化を受けたかを知る目的で炭化室の炉壁，炣

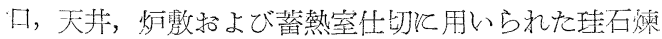
瓦とシャモット質檫沉ついて行った化学分析, 顕微 镜訌験，構成鉱物の変化，気孔率，比重等の測定結果 を看告する。
I. 試料

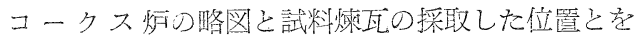
Fig.1飞示す. 次にこれらの外観と乞の断面の肉眼的

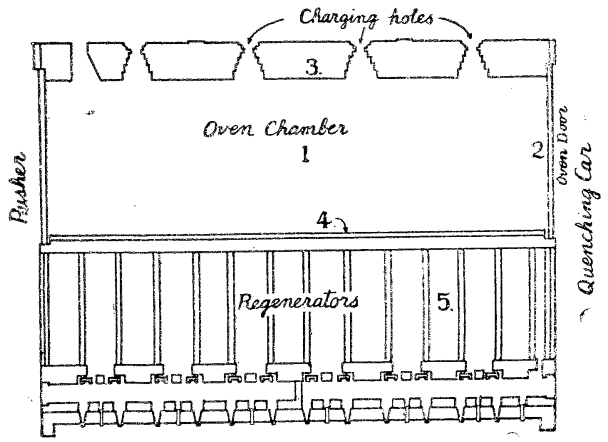

Fig. 1 Crorr section of colse-oven through oven chamber showing location of samples. 1-Oven wall brick. 2- Jamb brick. 3- Roor brick. 4- Sole brick. 5- Pillar wall brick.

变化について述べる.

試料 1：一崖化室壁中央部珪石煉瓦（Fig. 2)

炭化室側表面：一操業中心約 $1100^{\circ} \mathrm{C}$ 亿保たれ石若 が直接に接触した面で，炭素付着のため黒色を呈して いる. コークス押し出しのため出を生じている が触感は滑らかで方る・面の山出はマトリックス部が 
磨耗して拄石精部が飛び出して出来たと考えられる。

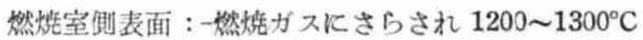
に保たれた面で，福色でざらざらした触䜿を有し所々 に径 1〜2 mm の小孔が出来ている.

断面：一嵪温部から見てゆくと然烧室側表面に近い 約 $5 \mathrm{~mm}$ は淡䄑色 (A-Zone) で, その隣の約 $1.5 \mathrm{~cm}$ は谈黄色 (B-Zone) である.とれより内部は赤紫色 (C-Zone) 上罢緑出 (D-Zone) の门約 $5 \sim 6 \mathrm{~cm}$ てお るが,この C 上 $\mathrm{D}$ 上の境界線は非常に不規則であ

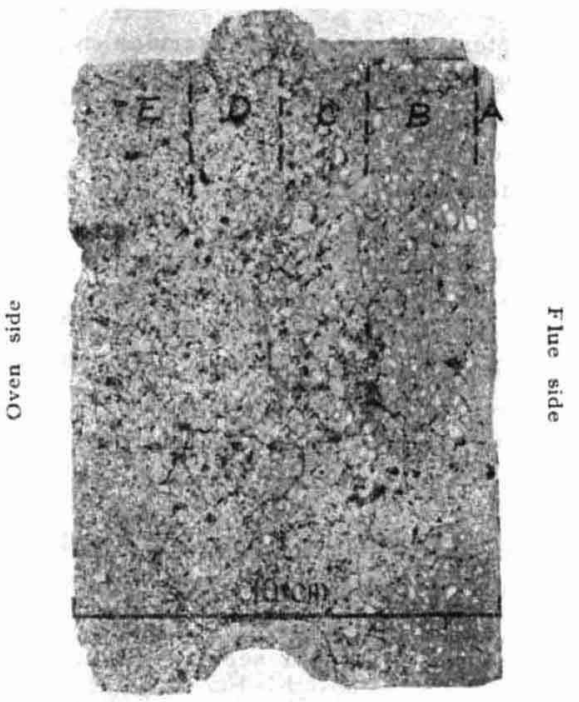

Fig. 2 Sample 1, Siliea brick from the centre of oven wall.

る. その降から炭化室側表面までの約 $2 \mathrm{~cm}$ は灭色 (E-Zone) である、帮瓦の中央解には萑干の小他裂が

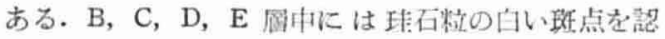
めるが, A 酋中には認められない。

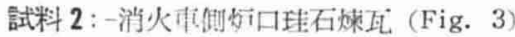

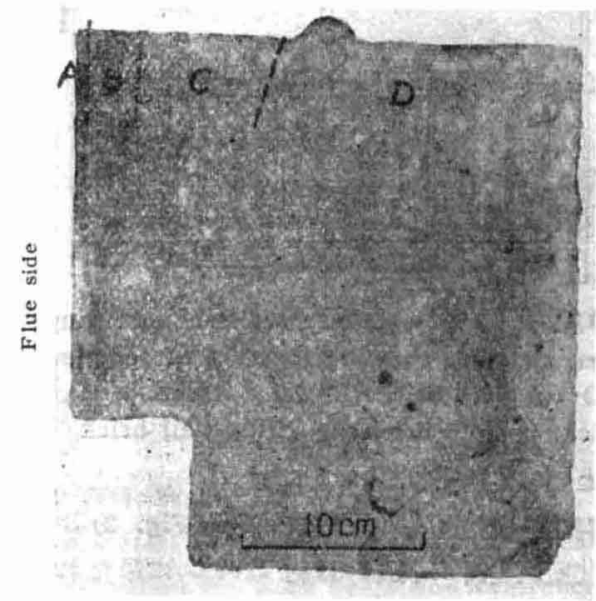

Oven door side

Fig. 3 Sample 2, Silica brick from the jamb on the side of quenching car.
炭化室側表面:-コークス出口の廝に接していでた面 コークス押出による磨耗とスボーリングとたら相当 損伤している.

然焼室側表面：-1200〜 $1300^{\circ} \mathrm{C}$ に保たれ然焼少スに

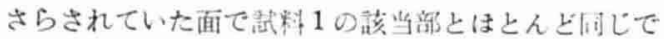
あるが小孔は少い。

断面: 一然烍室僋表面の約 $5 \mathrm{~mm}$ 程は淡袙色 (A)で, その搠は赤褐色の $4 \sim 5 \mathrm{~cm}$ の㴔 (B) となり, たん たん淡黄色 (C) となりやがて淡青色 (D) となる。こ れらの首の境界は㰾移的である。

試料 3 :-炭化室天井シャモット煤瓦 (Fig. 4)

炭化空側表面：一使用中は $1100^{\circ} \mathrm{C}$ 程度に保たれた死 炭よりの揮発性 Oven side 物空にさらされ ていた面で扊白 色の薄首が表面 に付着して大き な不規則な割れ 目が生してい 万.

断面: - 岸化室 側考面加 53 $10 \mathrm{~mm}$ は赤褞色 (A) 層でえれよ り内部入約 $3 \mathrm{~cm}$ は淡扊色 (B)て 漸次淡赤福色 (C) 加黃禓色 (D)に移行与る. 酰化鉄の轨点か

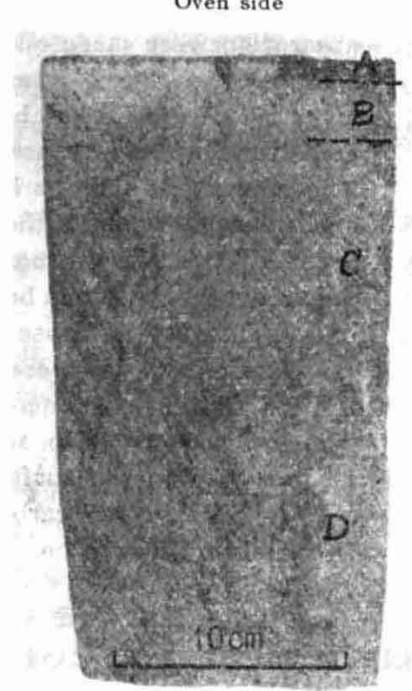

Fig. 4 Sample 3, Grog brick from the roof of oven chamber. 所々に見られる。

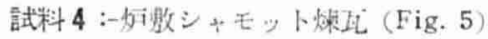

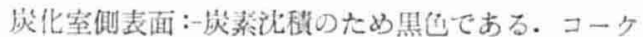
ス押出しのための磨摖条痕拈よび多数の大きな能甲状 割机目を生じている。

断面: 一断面に当ける温度勾配は非常に少かったと苽

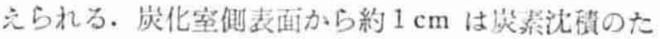

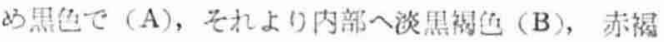
Oven side

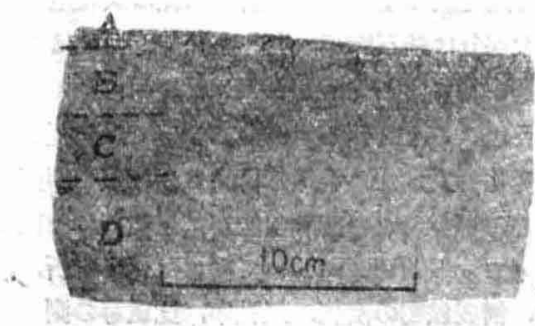

Fig. 5 Sample 4, Grog brick from the sole of oven chamber. 
色 (C), 淡赤褐色 (D) と漸移与る. 中間屇に特に酸 化鉄斑点が多い，全体的に炭化空側表面の収縮のため 弓状に若干僰曲している。

試料 5 :- 鳘熱空仕切理石煤瓦 (Fig. 6)

全体に淡黄褐色で元の妹瓦とほとんど変化がない， ただその断面において一端からウ数 $\mathrm{mm}$ 程度 (A) が 元の珪石粒の白斑が見られないためにこの部分が高温 端であったと想像され，をれより内部 (B) と他端 (C) は肉眼的に全く同样である.

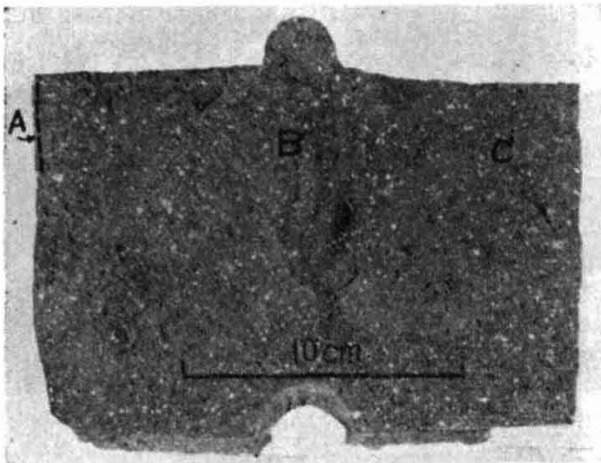

Fig. 6 Sample 5, Silica brick from the pillar wall in regenerator.

\section{II. 顕砤镜観察}

試料 1 (Fig. 7) :-燃焼室側表面に近い數 $\mathrm{mm}$ は遊 唯理酸は全部完全にトリジイト化している，その大

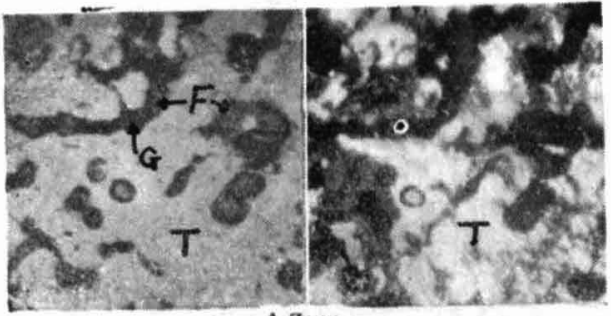

A.Zone

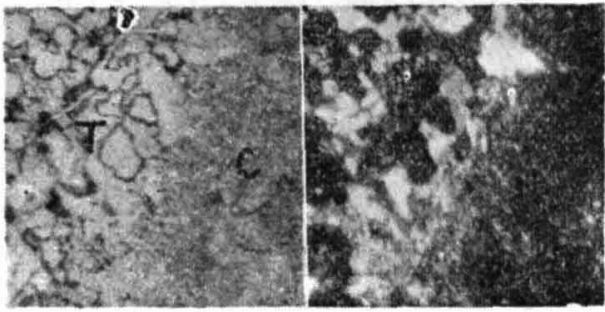

C.Zone

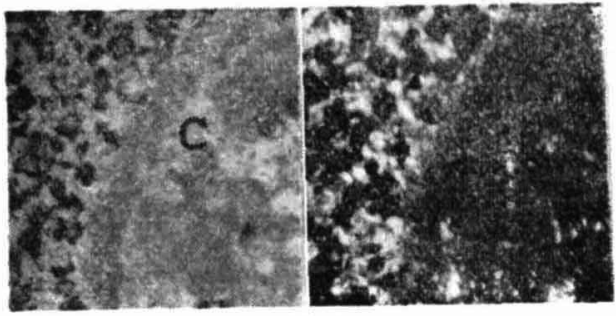

$1)$ Zune

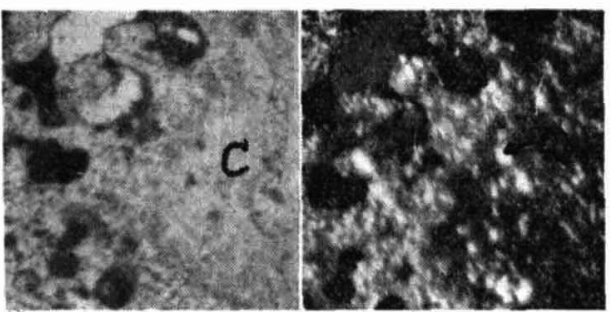

E-Zone

Fig. 7 Microphotograph of sample 1 (wall silica brick). Open nicols (left) and crossed nicols (right). Magnification $40 \times$. C ; Cristobalite. T: Tridymite. F : Fayalite. G: Glass. Q; Quartz.

きさは $0.07 \sim 0.2 \mathrm{~mm}$ 程夏の卓状結晶が大部分を占 めるが少量の帮型結晶も見られる.たくさんの丸い気 孔があり, 匃孔の内部には褐色の珄酸塩ガラスと考え られる光学的等方珄物質と, このガラス質物算から析 出したファイアライトと考えられる屈折率の高い黄色 微結晶と少量の黒色不透明鉱物とがある.これより低 温層では元の珪石粒の中央部はクリストバライトで, その周辺部からトリシマイト化しているのが見られ， 炭化空側表面に近くなるとしたがってトリシマイト転 移は少くなる、微量ではあるが残存石英もまた低温部 に多くなる，ガうス質は高温部では集合的であるが， 低温部では小さく分散的である. 以上の锶察結果は等

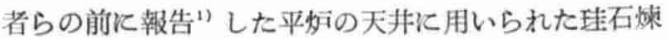

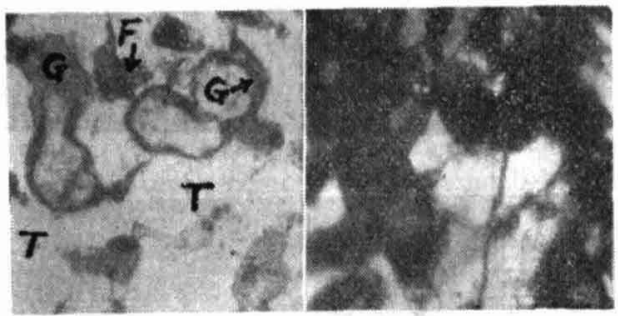

Fig. 8 Microphograph of lathshaped variety of tric y mise in a silica brick from coke oven wall. Cpen nicols (left) and crossed nicols (right). Magnification $10 \mathrm{~J} \times$. $\mathrm{T}$; Tridy mite. F; Fayalite. G; Glass

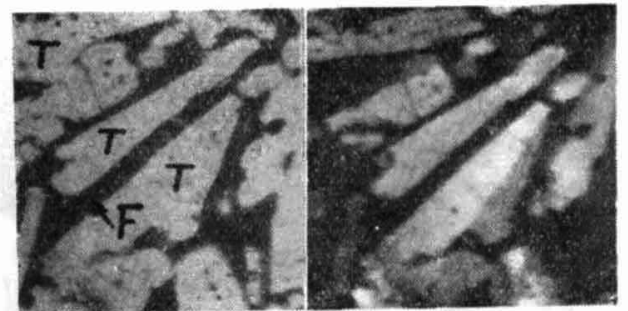

Fig. 9 Microphotograph of wedgeshaped variety of tridymite in a silica brick from roof of opeli hearth furnace. Open nicols (left) and crossed nicols (right). Magnification $10) \times$. 


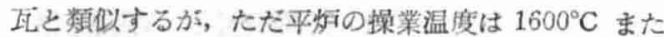
はそれ以上にも達する高温であったために，煤瓦の稼 働表面ではクリストバライト屏が生成していたこと と，それに隣接するトリジマイト周中のトリジマイト の結晶中には多くの㭢型結晶が徆められたこととが きな相違である. A. E. Dodd ${ }^{2)}$ その他の先行研究者 の教告によれば,トリジマイトの年状結晶よりも楔型 結唱の方が一層间温で安定であるとのことである. 㧱

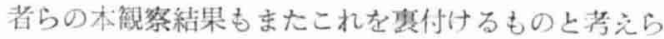
机る (Fig. 8,9 参㛃).

縒料 2 (Fig. 10):-全体的に試料 1 とはとえど同し である。然焼空側表面のトリシマイト結晶の大きさは 武料 1 の約半分で $0.05 \sim 0.12 \mathrm{~mm}$ 程度であった.カ

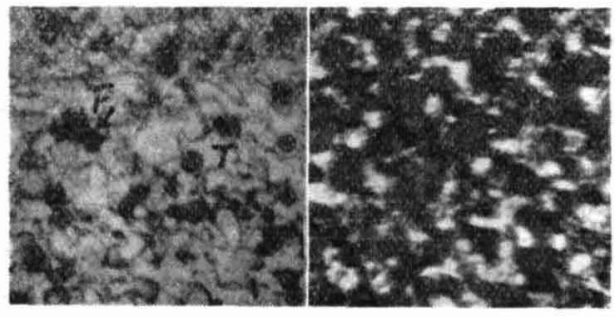

A.Zone

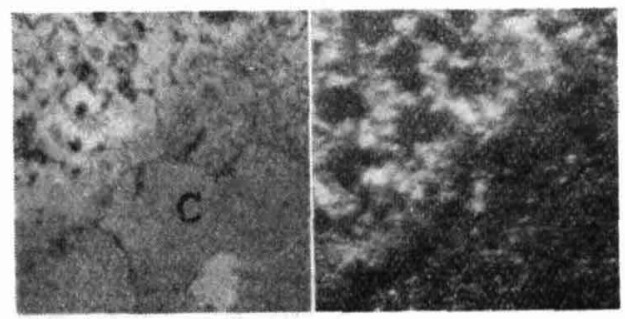

B-Zone

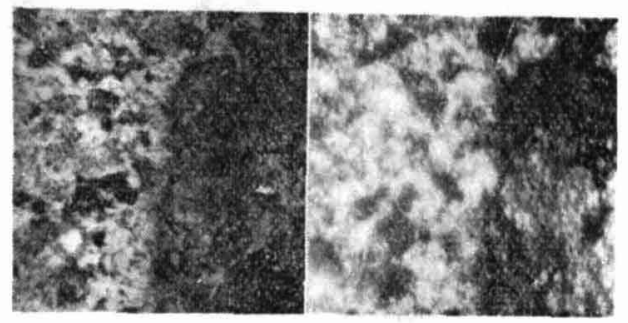

C.Zone

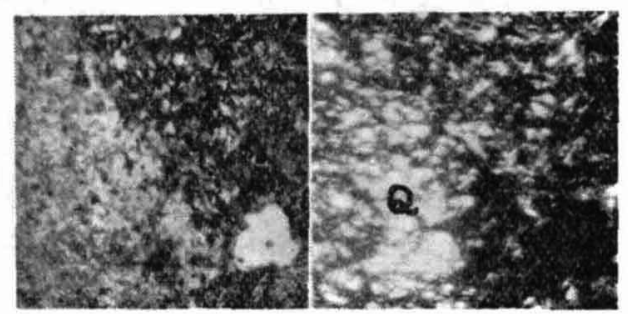

D.Zone

Fig. 10 Nicroplotozraph of sample 2 (jamb silica brick). Open nicols (leit) and crossed nicols (right). Magniaication $49 \times$.

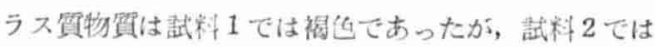
ほとんど無色で多数の小包变物を含んている。低温部 の残存石英は武料 1 より声やや多い.

試料 3 (Fig.11)：-荻化室僛表面は約 $1100^{\circ} \mathrm{C}$ で常 に石龙からの揮発物と接していた面で，炑瓦の他端は $700 \sim 800^{\circ} \mathrm{C}$ であったと澄像される。送化空側表面て

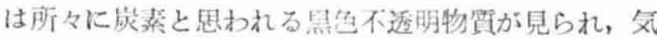
孔の表面，煤正の敖れ目に治って相当多くの酸化鉄の

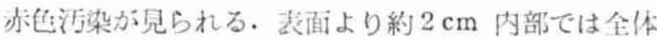

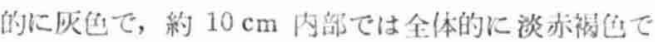
ある・

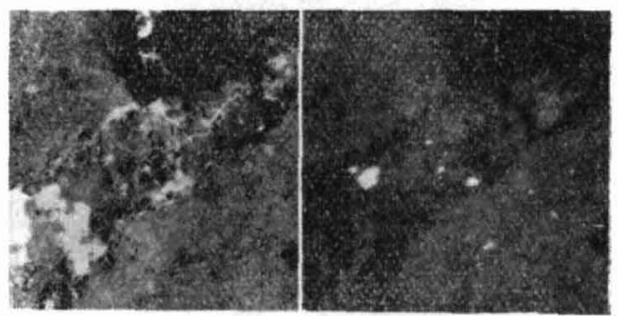

A-Zone

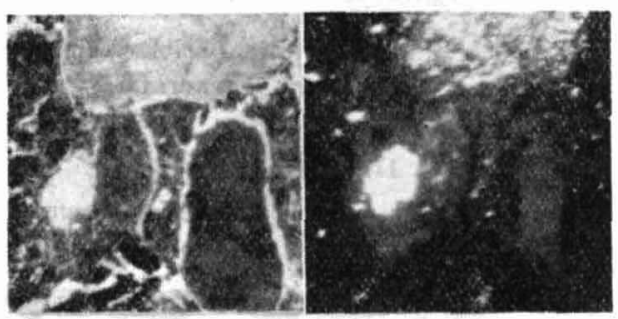

B-Zone

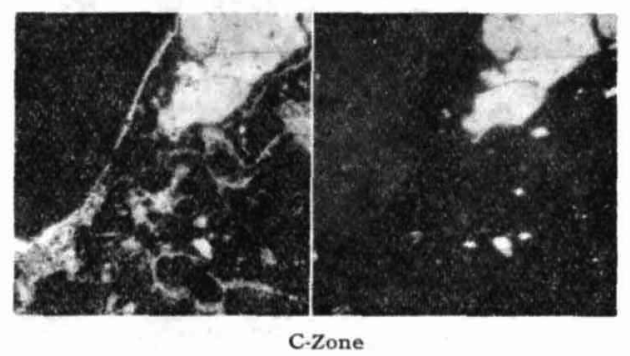

Fig. 11 Microphotograph of sample 3 (roof grog brick). Open nicols (left) and crossed nicols (right). Magnification $40 \times$.

試料4（Fig.12）：これはその下方の珪石煉瓦と共 に炭化室と薏熱室との隔垶となっていたもので，した がって温度勾配は非常に少い，炭化室側表面に近い所 は煉瓦中に多量の炭瑟が复入乙推程している. 0.05 $\mathrm{mm}$ 程度の石英のままの破片が所々儿ある。不純物 を多量に含んだ球石精はクリストバライトに転移し， その周囲はトリジマイトの微晶に答化しているが少量 である. 表面より 2〜 $2 \mathrm{~cm}$ 内部は全体的に死色で所 所に酸化鉄の小玟点があり $8 \sim 9 \mathrm{~cm}$ 内部では全体的 に桬袝色である。 


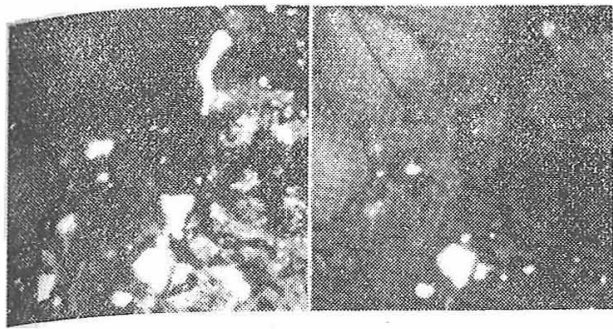

A.Zone

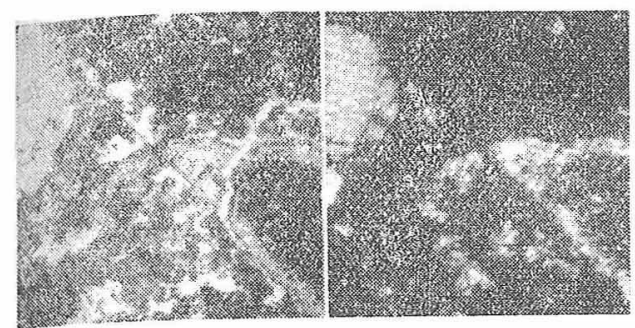

B-Zone

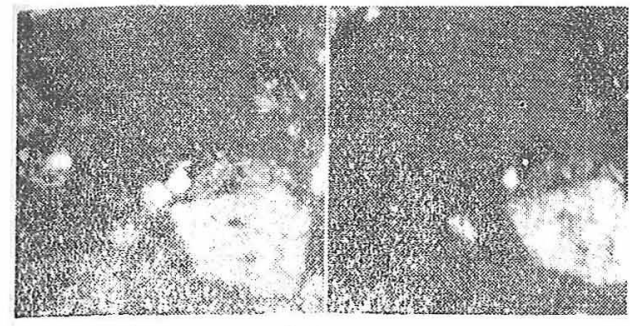

C.Zone

Fig. 12 Microphotograph of sample 4 (sole grog brick). Open nicols (left) and crossed nicols (right). Magnification $40 \times$.

試料 5 (Fig. 13)：-試料 2 によく似ている. 㦈熱室 内部の高温㴼の币数 $\mathrm{mm}$ はトリジマイと少量のフ アイアライトからなる。トリジマイはは卓状結晶が大

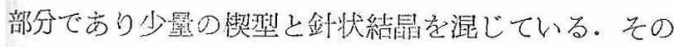
大きさも試料 2 と同秷度である.ガラス物質はほとん

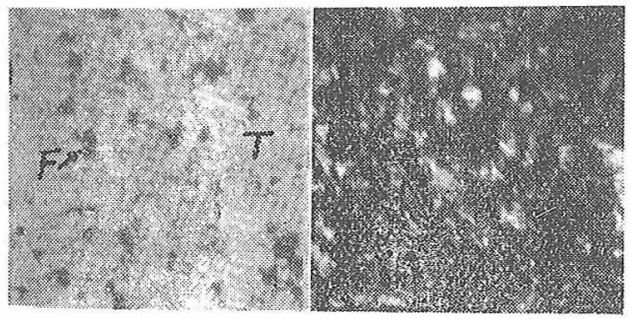

A.Zone

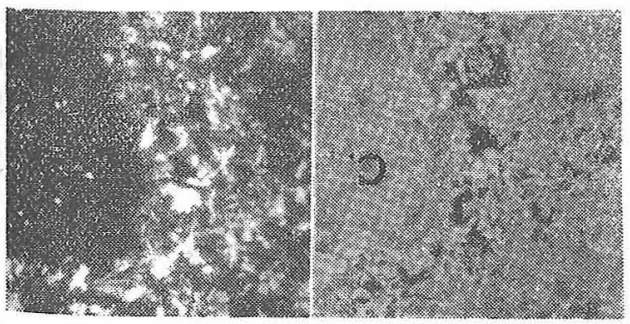

B-Zone

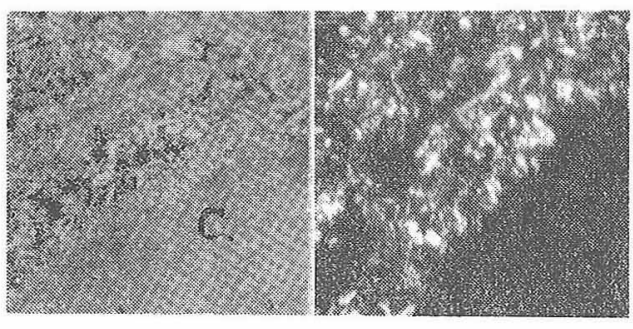

C-Zone

Fig. 13 Microphotograph of sample 5 (pillar wall silica brick). Open nicols (left) and crossed nicols (right). Magnification $40 \times$.

ど見られない。これるり内氺の呧温部ではクリストバ シイトが多くなる。残存死英は非常心少心。

\section{III。權成鈸物の定量}

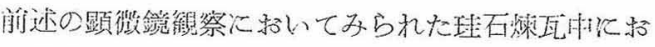
ける䧼成鉱物の生成比を定量する目的で，樍分求積器 (Integration stage) を用いて测定した。測定方法に

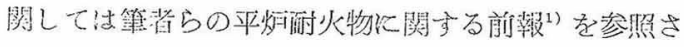

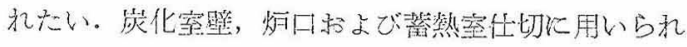

Table 1 Volume ratio of constituent minerals in each layer zone in the oven wall brick (Sample 1)

$\begin{array}{lcrrrc}\text { Layer zone } & \text { A } & \text { B } & \text { C } & \text { D } & \begin{array}{c}\text { E } \\ \text { (Oven side) }\end{array} \\ \text { Quartz } & 0 & \text { tr. } & \text { tr. } & \text { tr. } & 1 \\ \text { Cristobalite } & 0 & 15 & 15 & 25 & 38 \\ \text { Tridymite } & 66 & 68 & 66 & 50 & 54 \\ \text { Fayalite } & 16 & 4 & 6 & 5 & 3 \\ \text { Glass } & 14 & 11 & 10 & 8 & 3 \\ \text { Opaque Subst. } & 4 & 2 & 6 & 6 & 2\end{array}$

Table 2 Volume ratio of constituen't minerals in each layer zone in the jamb brick from quenching car side (sample 2)

\begin{tabular}{|c|c|c|c|}
\hline Layer zone & (Flue side) & B & $\mathrm{C}$ \\
\hline Quartz & 0 & tr. & 3 \\
\hline Cristobalite & 0 & 7 & 24 \\
\hline Tridymite & 74 & 74 & 61 \\
\hline Fayalite & 10 & 4 & 8 \\
\hline Glass & 16 & 13 & 2 \\
\hline Opaque subst. & $\operatorname{tr}$. & 2 & 2 \\
\hline
\end{tabular}

Table 3 Volume ratio of constiuent minerals in each layer zone in the pillar wall brick of regenerator (sample 5)

$\begin{array}{lrrr}\text { Layer zone } & \text { A } & \text { B } & \text { C } \\ \text { Quartz } & 0 & \text { tr. } & \text { tr. } \\ \text { Cristobalite } & 0 & 17 & 27 \\ \text { Tridymite } & 81 & 72 & 65 \\ \text { Fayalite } & 19 & 11 & 8 \\ \text { Glass } & \text { tr. } & \text { tr. } & \text { tr. } \\ \text { Opaque subst. } & \text { tr. } & \text { tr. } & \text { tr. }\end{array}$

た琵石罗工 （試料 1 ，2，5）の測定結果を Table 1, 2,3 に示す、測定結果を見るにいずれ屯高温端では遊離珪 酸は全部トリジマイトル転移しているが，低温部に行 くにしたがいクリストバライトと残存石英が壃加して 
いる、また，ガラス質とファイアライトと考光られる 淡黄色珪酸塩鉣物は試料 1 では中間風に，試料 2 では 然焼室側高温端飞多いことは次の化学分析の結果とも よく一致する.

Table 4 Chemical analysis of each layer zone in the oven wall brick (sample 1)

$\begin{array}{lcccc}\text { Layer zone } & \begin{array}{c}\mathrm{A}-\mathrm{B} \\ \text { (Flue side) }\end{array} & \mathrm{C} & \mathrm{D} & \begin{array}{c}\mathrm{E} \\ \text { (Oven side) }\end{array} \\ \mathrm{SiO}_{2} & 92.38 \% & 91.75 \% & 91.84 \% & 94.13 \% \\ \mathrm{TiO}_{2} & 0.03 & 0.05 & 0.05 & 0.04 \\ \mathrm{Al}_{2} \mathrm{O}_{3} & 1.72 & 1.70 & 2.14 & 1.61 \\ \mathrm{Fe}_{2} \mathrm{O}_{3} & 1.38 & 0.82 & 0.57 & 0.00 \\ \mathrm{FeO} & 0.90 & 1.78 & 1.80 & 1.72 \\ \mathrm{MnO} & 0.07 & 0.21 & 0.31 & 0.15 \\ \mathrm{CaO} & 2.55 & 2.79 & 3.15 & 2.23 \\ \mathrm{MgO} & 0.04 & 0.04 & 0.10 & 0.09 \\ \mathrm{Na} & 0.14 & 0.13 & 0.10 & 0.07 \\ \mathrm{~K}_{2} \mathrm{O} & 0.10 & 0.14 & 0.07 & 0.05 \\ \mathrm{C} & 0.12 & 0.21 & 0.26 & 0.19 \\ \mathrm{~S} & 0.04 & 0.03 & 0.02 & 0.04 \\ \text { Total } & 99.47 & 99.65 & 100.41 & 100.32\end{array}$

Table 5 Chemical analysis of each layer zone in the jamb brick from the quenching car side (sample 2)

\begin{tabular}{|c|c|c|c|c|}
\hline Layer zone & ${ }_{(\text {Flue }}^{\text {A side) }}$ & B & $\mathrm{C}$ & $\mathrm{D}$ \\
\hline $\mathrm{SiO}_{2}$ & $91.77 \%$ & $93.88 \%$ & $93.86 \%$ & $93.56 \%$ \\
\hline $\mathrm{TiO}_{2}$ & 0.02 & 0.02 & 0.02 & 0.03 \\
\hline $\mathrm{Al}_{2} \mathrm{O}_{3}$ & 1.30 & 0.81 & 0.98 & 1.10 \\
\hline $\mathrm{Fe}_{2} \mathrm{O}_{3}$ & 0.84 & 0.65 & 0.32 & 0.36 \\
\hline $\mathrm{FeO}$ & 1.57 & 1.15 & 1.08 & 1.09 \\
\hline $\mathrm{MnO}$ & 0.30 & 0.21 & 0.19 & 0.20 \\
\hline $\mathrm{CaO}$ & 3.44 & 2.85 & 2.70 & 2.66 \\
\hline $\mathrm{MgO}$ & 0.02 & 0.09 & 0.12 & 0.16 \\
\hline $\mathrm{Na}_{2} \mathrm{O}$ & 0.53 & 0.59 & 0.49 & 0.53 \\
\hline $\mathrm{K}_{2} \mathrm{O}$ & 0.07 & 0.06 & 0.05 & 0.10 \\
\hline $\operatorname{Ig} \cdot \operatorname{loss}$ & 0.05 & 0.02 & 0.14 & 0.15 \\
\hline Total & 99.91 & 100.33 & 99.95 & 99.94 \\
\hline
\end{tabular}

Table 6 Chemical analysis of each layer zone in the oven chamber roof brick (sample 3)

\begin{tabular}{|c|c|c|c|}
\hline Layer zone & (Oven side) & B & $\mathrm{C}$ \\
\hline $\mathrm{SiO}_{2}$ & $49.02 \%$ & $48.05 \%$ & $49.50 \%$ \\
\hline $\mathrm{TiO}_{2}$ & 0.69 & 0.86 & 1.34 \\
\hline $\mathrm{Al}_{2} \mathrm{O}_{3}$ & 42.60 & 46.97 & 45.31 \\
\hline $\mathrm{Fe}_{2} \mathrm{O}_{3}$ & 3.28 & 1.46 & 2.32 \\
\hline $\mathrm{FeO}$ & 0.79 & 1.65 & 0.72 \\
\hline $\mathrm{MnO}$ & 0.06 & 0.03 & 0.03 \\
\hline $\mathrm{CaO}$ & 1.34 & 0.34 & 0.32 \\
\hline $\mathrm{MgO}$ & 0.38 & 0.25 & 0.23 \\
\hline $\mathrm{K}_{2} \mathrm{O}$ & 0.15 & 0.28 & 0.34 \\
\hline $\mathrm{Na}_{2} \mathrm{O}$ & 0.03 & 0.05 & 0.12 \\
\hline C & 0.19 & 0.02 & 0.02 \\
\hline $\mathrm{S}$ & 0.69 & 0.07 & 0.04 \\
\hline Total & 99.22 & 100.03 & 100.29 \\
\hline
\end{tabular}

Table 7 Chemical analysis of each layer zone in the oven chamber sole brick (sam. ple 4)

$\begin{array}{lccc}\text { Layer zone } & \text { A } & \mathrm{B} & \mathrm{C} \\ \mathrm{SiO}_{2} & 48.09 \% & 49.45 \% & 49.65 \% \\ \mathrm{TiO}_{2} & 0.76 & 0.65 & 0.61 \\ \mathrm{Al}_{2} \mathrm{O}_{3} & 42.75 & 47.78 & 47.74 \\ \mathrm{Fe}_{2} \mathrm{O}_{3} & 0.00 & 0.73 & 1.14 \\ \mathrm{FeO} & 1.74 & 1.08 & 0.68\end{array}$

$\begin{array}{lrcr}\mathrm{MnO} & 0.11 & 0.10 & 0.12 \\ \mathrm{CaO} & 0.53 & 0.06 & 0.06 \\ \mathrm{MgO} & 0.09 & \operatorname{tr} . & \mathrm{tr} \\ \mathrm{K}_{2} \mathrm{O} & 0.51 & 0.29 & 0.31 \\ \mathrm{Na}_{2} \mathrm{O} & 0.22 & 0.03 & 0.00 \\ \mathrm{C} & 5.06 & 0.05 & 0.02 \\ \mathrm{~S} & 0.20 & 0.14 & 0.04 \\ \text { Total } & 100.06 & 100.36 & 100.37\end{array}$

\section{IV. 化学分析}

これらの試料煤瓦の各首の化学分析の結果走 Table 4, 5, 6, 7 飞示す. 分析法は日本工業規格に準じた。た だし,炭素は直接燃燒ガス容量法によった。すなわち, 試料を磁製ボートに採り $1150 \sim 1200^{\circ} \mathrm{C}$ に加熱した燃 焼管に入れて酸素を送り，燃焼好しめて $\mathrm{CO}_{2}$ とし， 過剩の酸素と共に一定量のビュレットに採り，これを

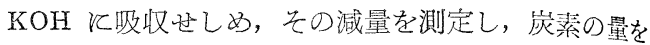
算出した．分析結果を見るに，武料1ではアルミナ， 石庅，マンガン扔よび酸化鉄の含有量は中間層に増加 を示している。これらの酸化物を含えだ低熔性珄酸㙁 の移動飞よるものと考えられる。次に鉄は酸化第一鉄 としては燃焼窒側に少く，酸化第二鉄は反対に然焼室 側に多く炭化空側には全く無かった。これは燃焼室側 では燃焼用に空気が充分飞供給されていたが，炭化室 側では常に石炭末たはコークスの存在のため強い還元 状態にあったためと考光られる。これらの酸化鉃の含 有量は中間層にやや增加しているが，全体としては然 焼室側に漸増している。これは S.S. $\mathrm{Cole}^{3)}$, W.C. Rueckel ${ }^{4}$ 等の報告と反対の結果を得た。次に試料 2 の分析結果を見ると，珪酸以外の不純物はすべて然焼 側表面飞急增乙ている。これらのことは燃焼に用いら

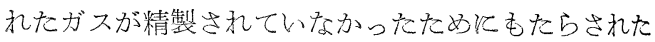
むのと思われる。禾た試料 1 で少量であるが硫黄の存 在を認めている。これは石炭または然㜔ガス中から侵 入乙て来たもので，前述した試料 1 亿䅂ける濃緑色， 赤紫色，淡黄色等の美しい色層はこの少量の硫黄湴起 因するものと考光られる。すなわら，無機顔料として の群青の合成飞匆いてその化学成分, 温度, 焼成時 間，雲囲気等のわずかの差異によって本来の美しい带 赤青色以外赤色，供色，緑色等が出来易いことはす でによく知られているとこるである。香た，この煉瓦 の色は空気中で強熱すれれ゙容易に褪色することからむ 揀瓦中に侵入して来た硫黄が気孔や割れ目の表面でマ トリックス成分と結合し，群青類似物が合成されたも の上考光られる，次に炭化室天井と炉敷煉瓦で毛各成 分の増減が晃られるが，このような変化は石若中の灰 成分や気化成分の侵入辸融剤作用之煉瓦中の温度 勾配と飞起因するものと䓅えられるが，その移則楼構 の詳細についてはな和明きらかではない。

V. 比重, 受孔率, 吸水率 


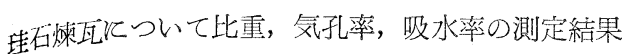
をTable 8, 9 亿示す. 測定方法は日本工業規格以準じ Table 8 Physical properties of each layer zone in the oven wall brick (sample 1)

\begin{tabular}{|c|c|c|c|c|c|}
\hline Layer zone & Flue side) & B & $\mathrm{C}$ & $D$ & (Oven eide) \\
\hline True Sp. Gr. & 2.32 & 2.32 & 2.33 & 2.35 & 2.32 \\
\hline Arucent Sp. Gr. & 2.31 & 2.30 & 2.33 & 2.31 & 2.20 \\
\hline Bulk Sp. Gr. & 1.74 & 1.65 & 1.72 & 1.74 & 1.73 \\
\hline Porosity $\%$ & 24.41 & 28.34 & 25.70 & 24.49 & 23.12 \\
\hline Vater Absorption \% & 13.96 & 17.14 & 14.92 & 14.04 & 12.76 \\
\hline
\end{tabular}

Table 9 Physical properties of each layer zone in the jamb brick from the quenching car side (sample 2)

\begin{tabular}{lcrrr}
\multicolumn{1}{c}{ Layer zone } & A & \multicolumn{1}{c}{ B } & \multicolumn{1}{c}{ C } & \multicolumn{1}{c}{ D } \\
True Sp. Gr. & 2.36 & 2.33 & 2.34 & 2.34 \\
Apparent Sp. Gr. & 2.36 & 2.30 & 2.33 & 2.33 \\
Bulk Sp. Gr. & 1.51 & 1.68 & 1.69 & 1.68 \\
Porosity \% & 35.70 & 26.58 & 27.40 & 27.95 \\
Water Absorption \% & 23.56 & 15.74 & 16.17 & 16.55
\end{tabular}

て行ったが，試料が小さいために特飞燃焼室側淡褐色 湖は試料 1,2 共飞厚さ $2 \sim 3 \mathrm{~mm}$ 飞ダイヤモンドカ ッターで切断し，10 g 程度のものを用いたために実 的誤差は相当大きくなったと考兄られる。燃焼室側表 面の真比重が比較的大きいのは，化学分析の結果から も知られるように不純物が多く侵入していたためと考 えられる。

\section{綜括}

第三次大戦の未期に6 年間使用された 75 門より成 る日鉄複式コークス炣の炭化室の壁珪石煉瓦，炉口珪 石煉瓦，天井シャモッ卜煉瓦，炉敷シャモッ卜煉瓦拉 よび䈉熱室仕切煉瓦の5 種の煉瓦について，その使用 中受けた変化について研究し, これらの煉瓦中の各

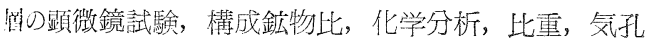
而, 吸水率の測定結果を報告した。その結果, 次のこ 上が知られた。

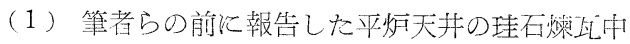
つトリジマイトは多くの楔型結晶が見られたが，本報 楅中の理石煉瓦では.卓状結晶が大部分で揳型のものは 少量であった。これはトりシマイトの卓状結晶よりも 舆型結晶の方が高温比称いて安定であるという先行研
究者の説を裏書きするすのである。

（2）壁珪石煉瓦中のガラス質物は褐色であった が，炉口珪石煉瓦中のものは㴗とんど無色で，多くの 小包裹物を含有し，蓄熱室仕切珪石煉瓦中ではガラス はほとんど無かった。

（3）壁珪石煉瓦中で注酸化鉄，石灰等の不純物は 局部的には中間層に集中しているが，全体的には燃燒 室側に漸増の傾向で市った。これらの不純物は他の試 料の分析結果とも考古合わせ水ば然焼室側之炭化室側 との雨方から侵大したものと思われる。

（4）哣口珪石煉瓦中では不純物は燃焼室側表面以 多く、それより内部へ急減していた。すなわち，不純 物は燃焼室側表面から侵入したものである。

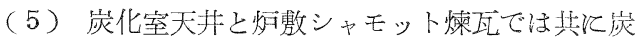
化室側表面飞多くの不純物を含えでいた。このことは 不純物が炭化室側より侵入したととを示すものであ る。

（6）以上 (3), (4),(5) の結果を総合する飞, 従 来コークス炻では煉瓦中への不純物の侵入は石炭灰以 ついてのみ注意されていたが，本研究の結果，燃燒室 からの侵入について，な杼一層の注意が必要であるこ と老知った。

（7）壁珪石煉瓦の緑，赤，黄等の美しい臽は石炭 からの硫黄が煉瓦中に侵大乙気孔，割れ目の表面でマ トリックス成分と結合して群青類似物が合成されたも のと推定される.

（8）炉㪤シャモット煉瓦の炭化室側表面汇は多量 の炭素が堆積していた。

（9）天井と炉敷シャモッ卜煉瓦は永久収縮が大き いために，その䃍働表面多くの龟裂を生じていた。

\section{引用交献}

1）青武雄・尾山竹滋・塞協，62，[697],23 (1954)

2) A.E. Dodd, Ceramics. a Symposium Brit.

Ceram. Soc., p. 208 (1953)

3) S.S.Cole, J. Am. Ceram. Soc., 9, 197 (1926)

4) W. C. Rueckel, J. Am. Ceram. Soc., 21354 (1938)

(12/19/55 受付) 